Science, Technology and Development 34 (3): 169-178, 2015

ISSN 0254-6418 / DOI: 10.3923/std.2015.169.178

(C) 2015 Pakistan Council for Science and Technology

\title{
Efficacy of Planting Seasons and Macro Nutritional Levels on Growth, Yield and Vase Life of Carnation Dianthus caryophyllus $\mathrm{L}$.
}

\author{
${ }^{1}$ Ahsan Akram, ${ }^{1}$ Gulzar Akhtar, ${ }^{2}$ Iftikhar Ahmad, ${ }^{1}$ Rashad Mukhtar Balal, \\ ${ }^{1}$ Muhammad Adnan Shahid, ${ }^{2,3}$ Adnan Younis and ${ }^{4}$ Shakeel Imran \\ ${ }^{1}$ University College of Agriculture, University of Sargodha, Sargodha, 40100, Pakistan \\ ${ }^{2}$ Institute of Horticultural Sciences, University of Agriculture, Faisalabad, 38040, Pakistan \\ ${ }^{3}$ Department of Horticulture Science, Kyungpook National University, Daegu, 702-701, Korea \\ ${ }^{4}$ Department of Crop Physiology, University of Agriculture, Faisalabad, 38040, Pakistan
}

\begin{abstract}
The present study was conducted to elucidate the effect of various planting seasons and macro nutritional (NPK) levels on vegetative, reproductive and vase life of carnation viz. Chaubad Mixed. There were two planting seasons (16th Nov. and 15th Feb.) and seven treatments (NPK combinations) were used. Planting season $S_{1}$ (16th Nov.) showed better results for indices like plant height, number of branches per plant, length of branches, number of leaves per plant, NPK contents, flower diameter, fresh weight of flower, fresh and dry weight ratio and flower quality as compared to planting season $\mathrm{S}_{2}$ (15th Feb.). However, regarding treatments, $\mathrm{T}_{2}$ (5:10:10 $\mathrm{g} \mathrm{pot}^{-1} \mathrm{NPK}$ ) showed positive correlation for morpho-physiological and bio-chemical traits like plant height, number of branches per plant, length of branches, number of leaves per plant, chlorophyll contents, NPK estimation and bud diameter by showing maximum values for the attributes with comparison to other treatments.
\end{abstract}

Key words: Carnation, NPK, nutrition, vase life, vegetative growth

\section{INTRODUCTION}

Carnation (Dianthus caryophyllus), a member of family caryophyllaceae, is a perennial flower which is mostly grown as annual in Pakistan. It has a variety of characteristics such as different growth habits, colors, sizes and its peculiar fragrance, which is a source of aesthetic gratification for the human beings. The plant is not only used for its garden beauty but has also been commercialized for its cut flowers. The species caryophyllus was once used as the generic name for clove, the basic fragrance of carnation, the common name; carnation is likely derived from "coronation" as the Greeks wove Dianthus flowers into crowns for their athletes. Carnation is indigenous to the Mediterranean region. In the world, areas of "natural climates" for carnation generally occur near $30^{\circ} \mathrm{N}$ or S latitude and on the Western edges of the continents. Examples are Southern California, the Mediterranean area and near Perth, Australia.

Carnation requires well balanced fertilizers application for optimum growth and quality production. The finest amount of nitrogen results in high flower yield in scania red carnation (Bloome and Roels, 1977). An increase in nitrogen level increased the growth and greatly increased stalk length and number of gladiolus flowers (Shah et al., 1984). By increasing nitrogen application, characteristics like plant height, number of branches per plant and seed yield become more whereas by increasing phosphorus number of pods per plant become greatest in Impatiens balsamina (Kumar and Kaur, 1996). Similarly, Khan et al. (2004) reported that Zinnia elegans cv. Meteor responded better to nitrogen application for improving its vegetative and floral characteristics.

Proper amount of fertilizer is indeed a secret of success and increase yield by enhancing the number and size of flowers (Damke and Bhattacharjee, 1997). Moreover, balanced nutrition also increases the vegetative and reproductive phase of growth (Sharaf and Ei-Naggar, 2003). Carnations are relatively slow growing plants. Therefore, it is utmost important for carnation grower to apply nutrients in the right quantity and frequency.

Carnation is high demanded in international cut flower market but short vase-life is major difficulty for distant marketing. Vase life allows some flexibility to regulate the market by supply of flowers during moderate market period and for having a greater supply during higher demand period. Carnation cultivars differ in length of their vase life (Nukui et al., 2004) which is one of the characteristics determining the commercial value of the 
ornamental flowers. As, there is an increasing demand for using carnations as a cut flower crop in the world including Pakistan, improved post harvest and maintenance techniques for extension of its vase-life are of greater economic importance.

The objective of this study was to elucidate the effect of best planting season and optimum level of macro nutrients (NPK) with suitable combination to get vigorous plant growth, maximum flower production and extension of vase-life of carnation flowers.

\section{MATERIALS AND METHODS}

Present study project was executed in greenhouse, Floriculture Research Area, Institute of Horticultural Sciences, University of Agriculture, Faisalabad. Nursery was raised in greenhouse on finely prepared separate beds containing silt, sand and well rotten F.Y.M. (1:1:1). After sowing in greenhouse, light irrigation was given to plants. After two months of sowing, seedlings were transplanted into the 10 inches pots filled with silt and coal having 20:1 ratio according to the layout of the experiment. Prior to transplanting of seedling into pots, soil samples were collected randomly from the pots and were analyzed to check fertility status and other characteristics of the media. There were three plants in a treatment and seven treatments which were replicated twice and experiment was laid out according to completely randomized design with factorial arrangements. A commercial variety of carnation viz. Chabaud double mixed was planted in two different planting seasons viz. Autumn $\mathrm{S}_{1}$ (16th Nov.) and Spring $\mathrm{S}_{2}$ (15th Feb.) and compared to check their response to six combinations of NPK along with control.

Half dose of nitrogen with complete dose of phosphorus and potassium was applied according to treatments after one month of transplanting whereas remaining half dose of nitrogen will be applied after 30 days of first application. Nitrogen, phosphorus and potash will be applied in form of urea (46\%), single super phosphate (18\%) and sulphate of potash (50\%), respectively. Healthy and vigorously growing plants were selected and tagged according to layout of the experiment. All other cultural practices, e.g., irrigation, weeding, hoeing, staking, pinching and IPM etc. were similar for all treatments during entire period of the study.

Growth parameters: Different growth parameters plant height (cm); number of branches, length branches (cm), number of leaves plant ${ }^{-1}$, leaf area $\left(\mathrm{cm}^{2}\right)$ (measured by leaf area meter), chlorophyll contents of leaves $\left(\mathrm{mg} \mathrm{g}^{-1}\right.$ ) (measured by chlorophyll meter) were measured.

Other growth attributes like days to first flower emergence; number of flowers plant ${ }^{-1}$ flower diameter $(\mathrm{cm})$, fresh weight of a flower ( $\mathrm{g}$ ), dry weight of a flower (g), fresh and dry weight ratio, flower quality and vase life (days) were observed.

For determining leaf analysis for nutrient procedure described by Van Lierop (1976) was used. Phosphorus was determined by spectrophotometer using standard curve (Hand Book 60, Method 61). Potash was determined with flame photometer (Hand Book 60, Method 5). A graded series of standards of KCL was prepared and standard curve was drawn. The values of $\mathrm{K}$ from flame photometer were compared for standard curve and total quantities were computed.

Data was analyzed statistically by using Fisher's analysis of variance technique and treatment means were compared by using Tuckey's test at 5\% probability level (Steel et al., 1997).

\section{RESULTS AND DISCUSSION}

Results revealed significant differences for plant height among planting seasons, macro nutritional levels and interaction between planting season and macro nutritional levels. As for as planting season $\mathrm{S}_{1}$ (16th Nov.) was concerned, $\mathrm{T}_{2}$ (5:10:10 $\mathrm{g} \mathrm{pot}^{-1} \mathrm{NPK}$ ) produced tallest plants with $91.39 \mathrm{~cm}$ plant height followed by $\mathrm{T}_{1}$ (5:5:10 $\left.\mathrm{g} \mathrm{pot}^{-1} \mathrm{NPK}\right)$ with $87.80 \mathrm{~cm}$ and $\mathrm{T}_{3}$ (5:15:10 g pot ${ }^{-1} \mathrm{NPK}$ ) with $75.17 \mathrm{~cm}$ height. While, $\mathrm{T}_{0}$ (Control) and $\mathrm{T}_{6}\left(10: 15: 10 \mathrm{~g} \mathrm{pot}^{-1} \mathrm{NPK}\right)$ were at bottom with 68.58 and $56.67 \mathrm{~cm}$ plant height (Fig. 1). Regarding planting season $S_{2}$ (15th Feb.), it was observed that $T_{2}$ (5:10:10 g pot ${ }^{-1} \mathrm{NPK}$ ) excelled rest of the treatments by producing tallest plants with $82.20 \mathrm{~cm}$ plant height followed by $T_{1}\left(5: 5: 10 \mathrm{~g} \mathrm{pot}^{-1} \mathrm{NPK}\right)$ with $79.99 \mathrm{~cm}$ height. While $T_{5}\left(10: 10: 10 \mathrm{~g} \mathrm{pot}^{-1} \mathrm{NPK}\right)$, T0 (Control) and $\mathrm{T}_{6}\left(10: 15: 10 \mathrm{~g} \mathrm{pot}^{-1} \mathrm{NPK}\right)$ were at bottom with 67.00 , 66.67 and $63.37 \mathrm{~cm}$ plant height. Above results were in line with Default (1987), Van Iersel et al. (1998) and Indrajit and Nilimesh (2003), who observed that N (Urea) and P (SSP) at $200 \mathrm{ppm}$ were applied resulted in highest plant height $(44.69 \mathrm{~cm})$, side shoots (12.44), leaves (523.17) and number of flowers (124.59), longest duration of flowering (147.35 days), vase life (7.33 days in tap water), flower stem length $(36.30 \mathrm{~cm})$ and flower weight (111.58 g/100 flowers). As for as planting seasons were concerned, it was observed that $S_{1}$ (16th Nov.) produced taller plants as compared to $S_{2}$ (15th Feb.). These finding collaborates with the findings of Zizzo et al. (1999) and Gursan (1999), who observed that Sep. and Jan. were found to be the best planting times for standard carnations.

Data regarding to number of branches is presented in Fig. 2 In planting season $S_{1}$ (16th Nov.), $T_{1}\left(5: 5: 10\right.$ g pot $^{-1}$ NPK) produced maximum with number of branches (48.23) followed by $T_{2}\left(5: 10: 10 \mathrm{~g} \mathrm{pot}^{-1} \mathrm{NPK}\right)$ with 46.60 and $\mathrm{T}_{3}\left(5: 15: 10 \mathrm{~g} \mathrm{pot}^{-1} \mathrm{NPK}\right)$ with 40.60 number 
Sci. Technol. Dev., 34 (3): 169-178, 2015

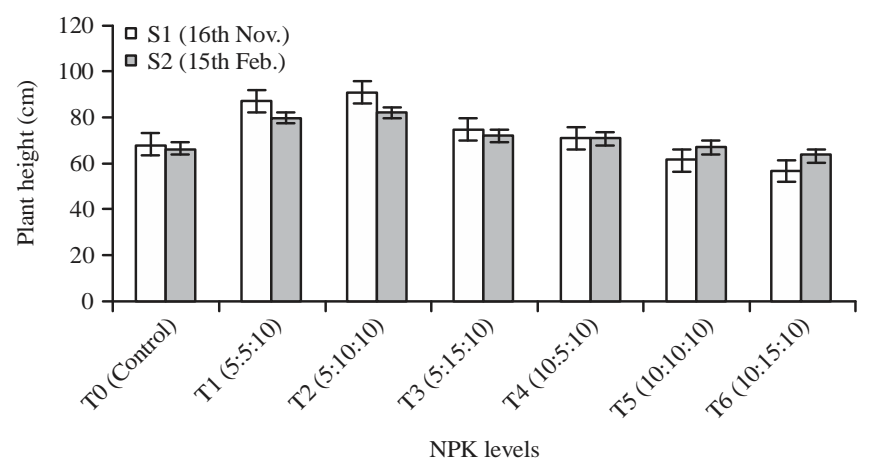

Fig. 1: Effect of planting seasons and macro nutritional (NPK) levels on plant height of carnation (Dianthus caryophyllus)

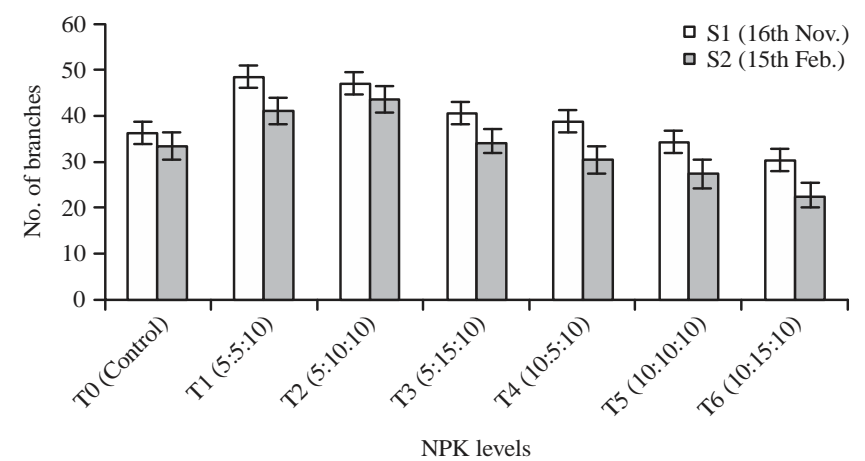

Fig. 2: Effect of planting seasons and macro nutritional (NPK) levels on number of branches of carnation (Dianthus caryophyllus)

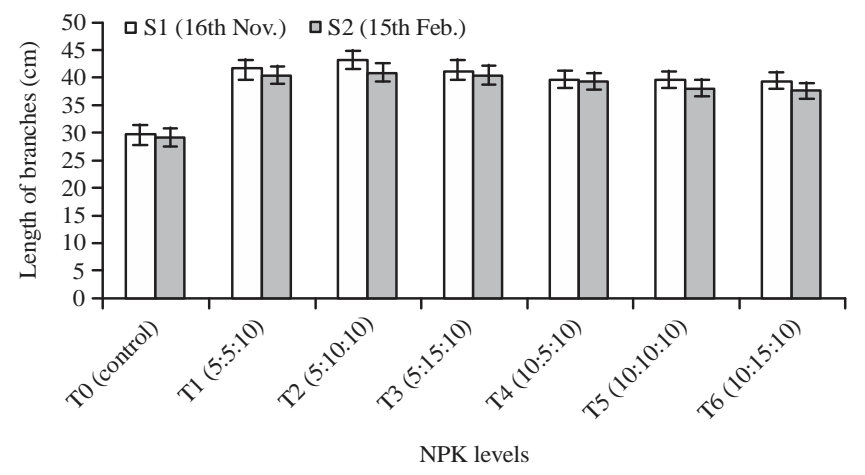

Fig. 3: Effect of planting seasons and macro nutritional (NPK) levels on length of branches of carnation (Dianthus caryophyllus)

branches plant ${ }^{-1}$. While $T_{6}\left(10: 15: 10 \mathrm{~g}\right.$ pot $\left.^{-1} \mathrm{NPK}\right)$ produced minimum 30.43 branches plant $^{-1}$. It is obvious that overall maximum branches plant ${ }^{-1}$ was observed in $\mathrm{T}_{2}$ (5:10:10 $\mathrm{g} \mathrm{pot}^{-1} \mathrm{NPK}$ ) that expressed significant superiority over other treatments and $T_{1}\left(5: 5: 10 \mathrm{~g} \mathrm{pot}^{-1}\right.$ NPK) occupied second best position. It may also be stated that more nitrogen more will be plant height or vice versa. It can safely be said that application nitrogen is helpful for the development and consequent flowering the single dose of $\mathrm{P}$ was applied, no matter how much $\mathrm{N}$ is applied. These results are with Default (1987), Van Iersel et al. (1998) and Indrajit and Nilimesh (2003). In case of planting season $S_{1}$ (16th Nov.) produced maximum number of branches as compared to $S_{2}$ (15th Feb.). These finding collaborates with the findings of Zizzo et al. (1999) and Gursan (1999).

It is obvious from the Fig. 3 that overall maximum length of branches plant $^{-1}$ were observed 
Sci. Technol. Dev., 34 (3): 169-178, 2015

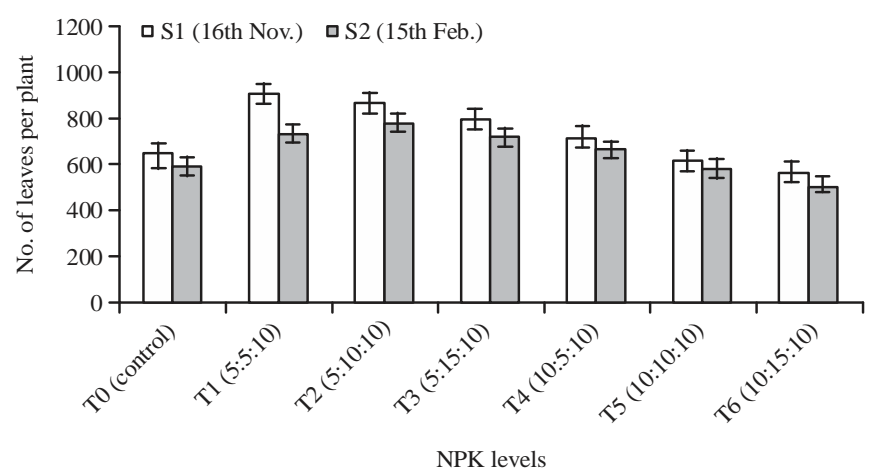

Fig. 4: Effect of planting seasons and macro nutritional (NPK) levels on number of leaves per plant height of carnation (Dianthus caryophyllus)

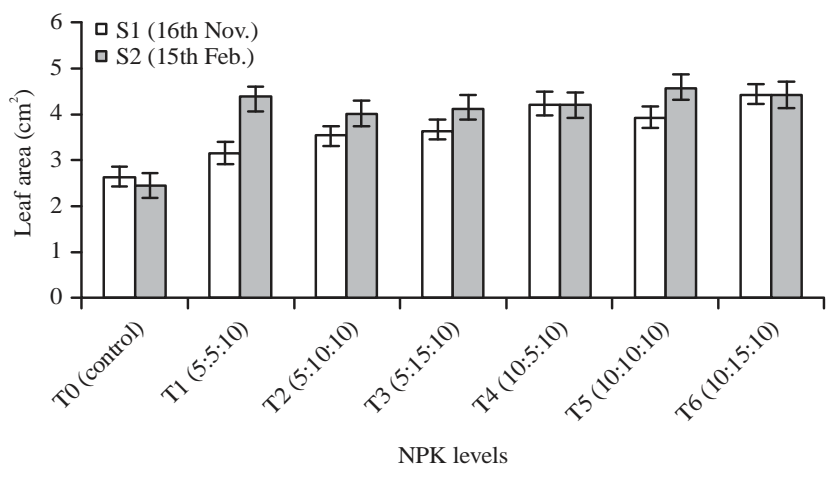

Fig. 5: Effect of planting seasons and macro nutritional (NPK) levels on leaf area of carnation (Dianthus caryophyllus)

in $\mathrm{T}_{2}$ (5:10:10 $\left.\mathrm{g} \mathrm{pot}^{-1} \mathrm{NPK}\right)$ that expressed significant superiority over other treatments and $\mathrm{T}_{1}\left(5: 5: 10 \mathrm{~g} \mathrm{pot}^{-1}\right.$ NPK) occupied second best position. Length of branches directly related to the Nitrogen fertilizer applied to the soil. But the fertilizer applied in combination always showed good performance as compared to fertilizer application as a single entity. There may be certain mechanisms of growth involved in increasing length of branches which are activated only in the presence of both $\mathrm{N}$ and $\mathrm{P}$ although the single dose of $\mathrm{P}$ was applied, no matter how $\mathrm{N}$ is applied. These results are in line with Default (1987), Van Iersel et al. (1998) and Indrajit and Nilimesh (2003).

In planting season $S_{1}$ (16th Nov.), $T_{1}\left(5: 5: 10\right.$ g pot $^{-1}$ NPK) produced maximum 908.12 number of leaves plant $^{-1}$ followed by $\mathrm{T}_{2}$ (5:10:10 g pot $\left.^{-1} \mathrm{NPK}\right)$ with 869.83 and $\mathrm{T}_{3}$ (5:15:10 $\mathrm{g} \mathrm{pot}^{-1} \mathrm{NPK}$ ) with 803.17 leaves plant ${ }^{-1}$. Regarding planting season $S_{2}$ (15th Feb.), $T_{2}$ (5:10:10 g pot $^{-1}$ NPK) produced maximum leaves plant ${ }^{-1}$ with 784.83 followed by $T_{1}\left(5: 5: 10 \mathrm{~g} \mathrm{pot}^{-1} \mathrm{NPK}\right)$ and $\mathrm{T}_{3}$ (5:15:10 g.pot ${ }^{-1}$ NPK) with 731.83 and 720.00 leaves plant $^{-1}$, respectively (Fig. 4). These finding collaborates with the findings of Zizzo et al. (1999) and Gursan (1999), who observed that Sep. and Jan. were found to be the best planting times for standard carnations.
Data presented in Fig. 5 showed that $\mathrm{T}_{6}(10: 15: 10$ g pot $^{-1} \mathrm{NPK}$ ) produced maximum $4.46 \mathrm{~cm}^{2}$ leaf area in $\mathrm{S}_{1}$ (16th Nov.) planting season while, $\mathrm{T}_{0}($ Control)) produced minimum $2.65 \mathrm{~cm}^{2}$ leaf area. $\mathrm{T}_{5}\left(10: 10: 10 \mathrm{~g} \mathrm{pot}^{-1} \mathrm{NPK}\right)$ produced maximum leaf area $4.60 \mathrm{~cm}^{2}$ planting season $\mathrm{S}_{2}$ (15th Feb.) but $\mathrm{T}_{0}$ (Control) produced minimum $2.45 \mathrm{~cm}^{2}$ leaf area. These results were contrast with the findings of Zizzo et al. (1999) and Gursan (1999), who observed that Sep. and Jan. were found to be the best planting times for standard carnations.

Maximum leaf chlorophyll contents (34.65 $\mathrm{mg} \mathrm{g}^{-1}$ ) were produced in planting season $\mathrm{S}_{1}$ (16th Nov.) at 5:5:10 $\mathrm{g} \mathrm{pot}^{-1}$ NPK. Minimum chlorophyll contents with 14.63 and $12.51 \mathrm{mg} \mathrm{g}^{-1}$ were produced in $\mathrm{T}_{5}$ (10:10:10 g pot ${ }^{-1}$ NPK) and $T_{6}\left(10: 15: 10\right.$ g pot $^{-1}$ NPK $)$ treatments (Fig. 6). In $\mathrm{S}_{2}$ (15th Feb.) planting season maximum leaf chlorophyll contents (38.89 $\mathrm{mg} \mathrm{g}^{-1}$ ) were produced in $T_{2}\left(5: 10: 10 \mathrm{~g} \mathrm{pot}^{-1} \mathrm{NPK}\right)$ and $\mathrm{T}_{5}$ $\left(10: 10: 10 \mathrm{~g} \mathrm{pot}^{-1} \mathrm{NPK}\right)$ and $\mathrm{T}_{6}\left(10: 15: 10 \mathrm{~g} \mathrm{pot}^{-1} \mathrm{NPK}\right)$ produced minimum 20.30 and $15.01 \mathrm{mgg}^{-1}$ chlorophyll contents, respectively.

Plants of carnation in $S_{1}$ (16th Nov.) planting season produced maximum nitrogen $(1.366 \%)$ at $\mathrm{T}_{2}$ (5:10:10 g pot $\left.{ }^{-1} \mathrm{NPK}\right)$ followed by $\mathrm{T}_{1}\left(5: 5: 10 \mathrm{~g} \mathrm{pot}^{-1}\right.$ NPK) by producing $1.22 \%$ nitrogen. $T_{6}\left(10: 15: 10\right.$ g pot $^{-1}$ 
Sci. Technol. Dev., 34 (3): 169-178, 2015

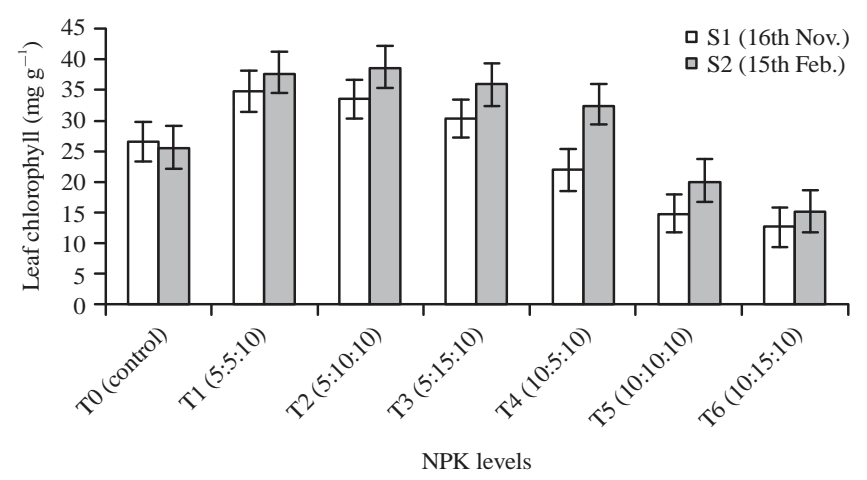

Fig. 6: Effect of planting seasons and macro nutritional (NPK) levels on leaf chlorophyll content of carnation (Dianthus caryophyllus)

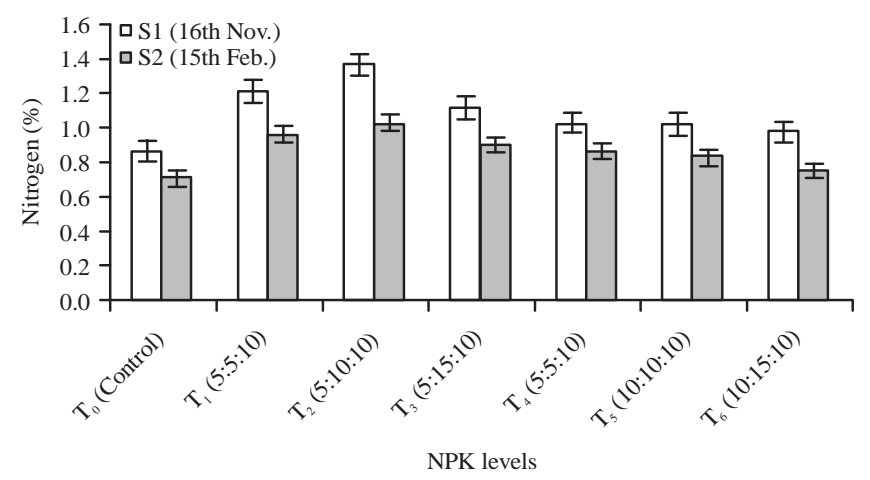

Fig. 7: Effect of planting seasons and macro nutritional (NPK) levels on nitrogen of carnation (Dianthus caryophyllus)

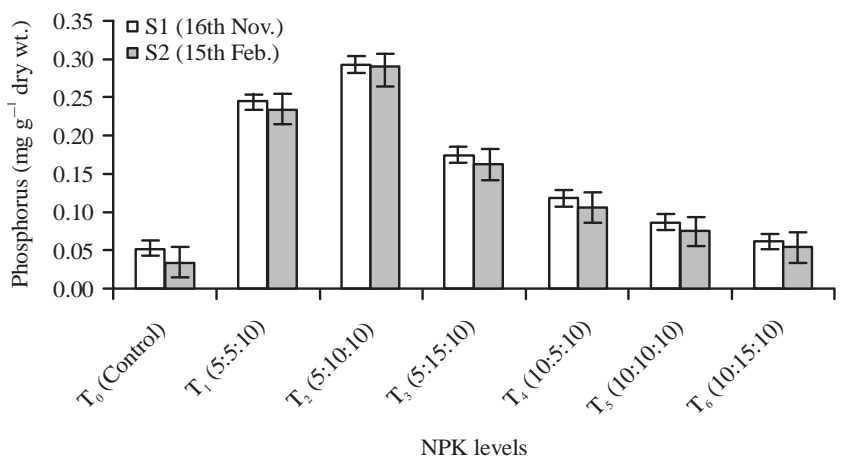

Fig. 8: Effect of planting seasons and macro nutritional (NPK) levels on phosphorus level in carnation (Dianthus caryophyllus)

$\mathrm{NPK}$ ) and $\mathrm{T}_{0}$ (Control) were least effective treatments by at bottom with $0.975 \% \mathrm{~N}$ and $0.884 \% \mathrm{~N}$, respectively. Maximum nitrogen $(1.027 \%)$ in $\mathrm{S}_{2}$ (15th Feb.) planting season was produced at $T_{2}\left(5: 10: 10 \mathrm{~g} \mathrm{pot}^{-1} \mathrm{NPK}\right)$ followed by $\mathrm{T}_{1}\left(5: 5: 10 \mathrm{~g} \mathrm{pot}^{-1} \mathrm{NPK}\right)$ with $0.961 \%$ nitrogen (Fig. 7). These in line with Default (1987) and Indrajit and Nilimesh (2003). S $\mathrm{S}_{1}$ (16th Nov.) planting season produces maximum nitrogen $\%$ age as compared to $\mathrm{S}_{2}$ (15th Feb) (Zizzo et al., 1999; Gursan, 1999).
In planting season $S_{1}$ (16th Nov.), $T_{2}$ (5:10:10 g pot $^{-1}$ NPK) produced maximum $0.293 \mathrm{mg} \mathrm{g}^{-1}$ dry wt. phosphorus followed by $\mathrm{T}_{1}$ (5:5:10 $\left.\mathrm{g} \mathrm{pot}^{-1} \mathrm{NPK}\right)$ with $0.243 \mathrm{mg} \mathrm{g}^{-1}$ dry wt. phosphorus, While $\mathrm{T}_{6}$ (10:15:10 $\mathrm{g} \mathrm{pot}^{-1} \mathrm{NPK}$ ) and $\mathrm{T}_{0}$ (Control) were at bottom by producing $0.055 \mathrm{mg} \mathrm{g}^{-1}$ dry wt. and $0.035 \mathrm{mg} \mathrm{g}^{-1}$ dry wt. phosphorus, respectively (Fig. 8). As for as planting season $\mathrm{S}_{2}$ (15th Feb.) is concerned, $\mathrm{T}_{2}$ (5:10:10 g pot $^{-1} \mathrm{NPK}$ ) produced maximum phosphorus with $0.286 \mathrm{mg} \mathrm{g}^{-1}$ dry wt. followed by $\mathrm{T}_{1}$ (5:5:10 $\mathrm{g} \mathrm{pot}^{-1}$ 


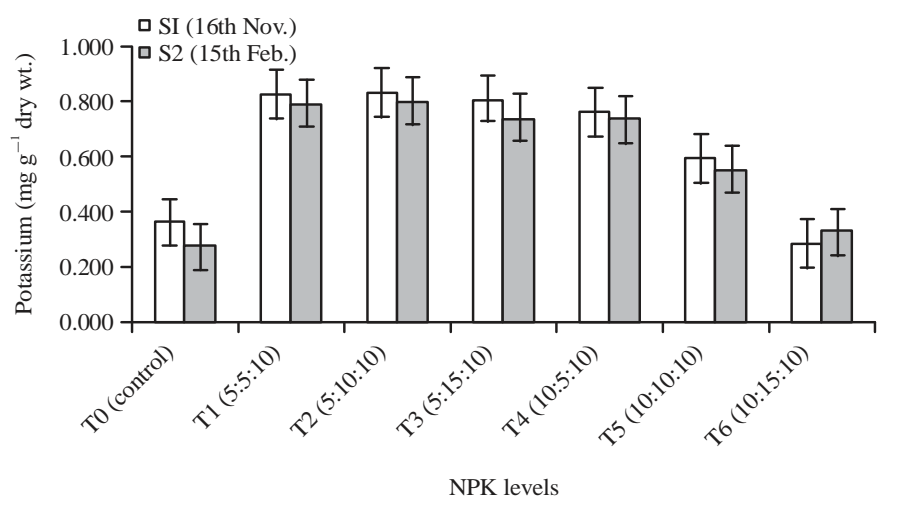

Fig. 9: Effect of planting seasons and macro nutritional (NPK) levels on potassium level in carnation (Dianthus caryophyllus)

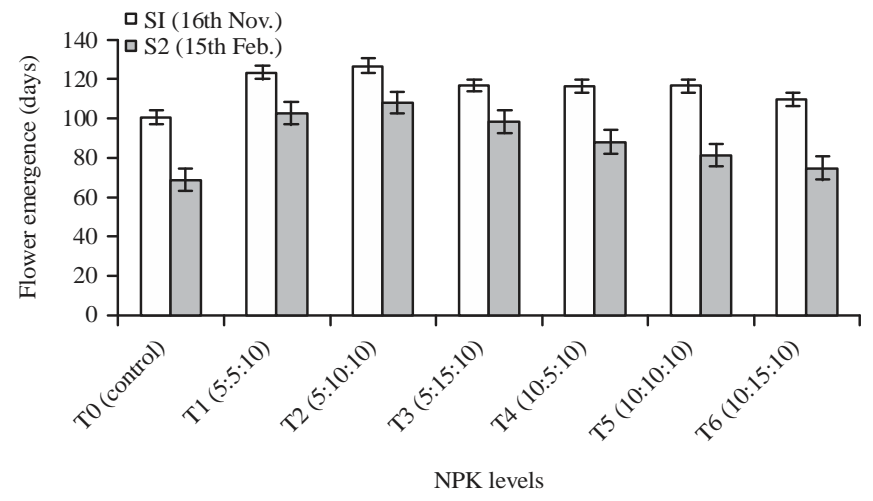

Fig. 10: Effect of planting seasons and macro nutritional (NPK) levels on flower emergence in carnation (Dianthus caryophyllus)

NPK) with $0.234 \mathrm{mg} \mathrm{g}^{-1}$ dry wt. phosphorus. Whereas, While $\mathrm{T}_{6}$ (10:15:10g pot $\left.{ }^{-1} \mathrm{NPK}\right)$ and $\mathrm{T}_{0}$ (Control) were at bottom with $0.055 \mathrm{mg} \mathrm{g}^{-1}$ dry wt. and $0.035 \mathrm{mg} \mathrm{g}^{-1}$ dry wt. phosphorus, respectively. These results are in accordance with the findings of Indrajit and Nilimesh (2003).

According to the data presented in Fig. $9 \mathrm{~T}_{2}$ (5:10:10 g pot ${ }^{-1} \mathrm{NPK}$ ) produced maximum potash with $0.843 \mathrm{mg} \mathrm{g}^{-1}$ dry wt. in $\mathrm{S}_{1}$ (16th Nov.) planting season. On the other hand While $\mathrm{T}_{0}$ (Control) and $\mathrm{T}_{6}$ (10:15:10 g pot $\left.^{-1} \mathrm{NPK}\right)$ produced minimum $0.362 \mathrm{mg} \mathrm{g}^{-1}$ dry wt. and $0.284 \mathrm{mg} \mathrm{g}^{-1}$ dry wt. potash, respectively. As for as planting season $S_{2}$ (15th Feb.) is concerned, $T_{2}$ (5:10:10 g pot ${ }^{-1} \mathrm{NPK}$ ) produced maximum potash with $0.806 \mathrm{mg} \mathrm{g}^{-1}$ dry wt. While, $\mathrm{T}_{6}$ (10:15:10 g pot $\left.^{-1} \mathrm{NPK}\right)$ and $\mathrm{T}_{0}$ (Control) were at bottom with $0.329 \mathrm{mg} \mathrm{g}^{-1}$ dry wt. and $272 \mathrm{mg} \mathrm{g}^{-1}$ dry wt. potash, respectively.

In both planting seasons $S_{1}$ (16th Nov.) and $S_{2}$ (15th Feb.), $\mathrm{T}_{0}$ (Control) took minimum days 101.12 and 69.52, respectively to first flower emergence of carnation. While treatment $\mathrm{T}_{2}\left(5: 10: 10 \mathrm{~g} \mathrm{pot}^{-1} \mathrm{NPK}\right)$ took maximum 127.66 and 108.79 days, respectively to first flower emergence (Fig. 10).

In planting season $\mathrm{S}_{1}$ (16th Nov.), $\mathrm{T}_{1}\left(5: 5: 10 \mathrm{~g} \mathrm{pot}^{-1}\right.$ NPK) produced maximum bud diameter $(1.90 \mathrm{~cm})$ followed by $\mathrm{T}_{2}\left(5: 10: 10 \mathrm{~g} \mathrm{pot}^{-1} \mathrm{NPK}\right)$ with $1.80 \mathrm{~cm}$. While, $\mathrm{T}_{5} \quad\left(10: 10: 10 \mathrm{~g}\right.$ pot $^{-1}$ NPK $)$ and $T_{6}$ (10:15:10 g pot $\left.{ }^{-1} \mathrm{NPK}\right)$ produced minimum $0.85 \mathrm{~cm}$ and $0.82 \mathrm{~cm}$ bud diameter. In planting season $\mathrm{S}_{2}$ (15th Feb.), $\mathrm{T}_{2}$ (5:10:10 $\left.\mathrm{g} \mathrm{pot}^{-1} \mathrm{NPK}\right)$ produced maximum bud diameter $(1.87 \mathrm{~cm})$ followed by $\mathrm{T}_{1}\left(5: 5: 10 \mathrm{~g} \mathrm{pot}^{-1} \mathrm{NPK}\right)$ with $1.77 \mathrm{~cm}$ (Fig. 11).

In both planting seasons $S_{1}\left(16\right.$ th Nov.) and $S_{2}(15$ th Feb.), maximum flower diameter $4.70 \mathrm{~cm}$ and $4.53 \mathrm{~cm}$ was produced in $\mathrm{T}_{3}$ (5:15:10 $\mathrm{g} \mathrm{pot}^{-1} \mathrm{NPK}$ ) respectively, While treatment $\mathrm{T}_{0}$ (control) produced minimum $3.17 \mathrm{~cm}$ and $2.33 \mathrm{~cm}$ flower diameter, respectively (Fig. 12).

In planting season $S_{1}$ (16th Nov.) was concerned, $\mathrm{T}_{1}$ (5:5:10 $\mathrm{g} \mathrm{pot}^{-1} \mathrm{NPK}$ ) produced maximum with 18.77 flowers plant ${ }^{-1}$ followed by $T_{2}$ (5:10:10 g pot $^{-1}$ NPK) with 13.90 flowers plant $^{-1}$. While 


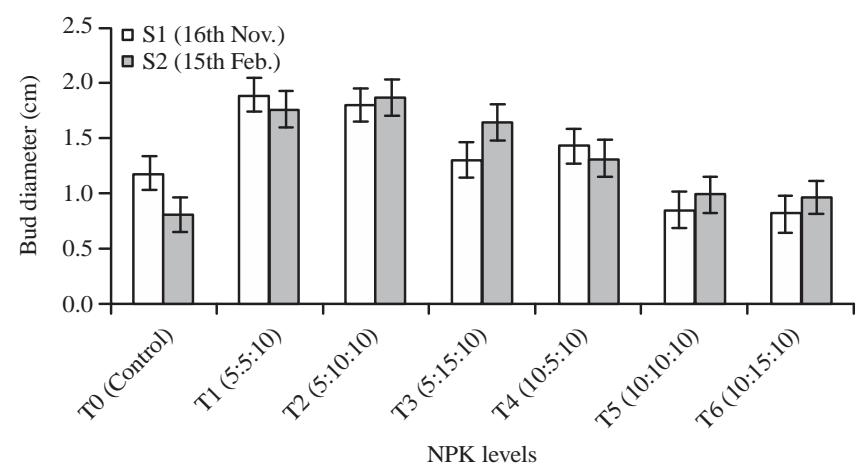

Fig. 11: Effect of planting seasons and macro nutritional (NPK) levels on bud diameter in carnation (Dianthus caryophyllus)

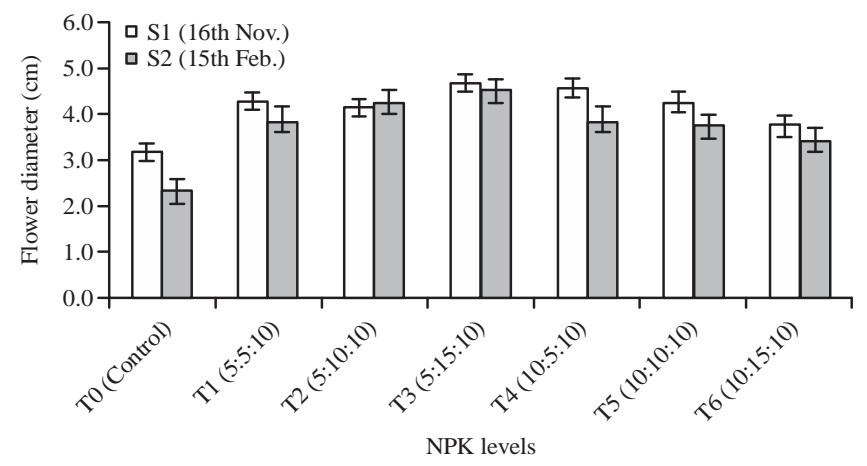

Fig. 12: Effect of planting seasons and macro nutritional (NPK) levels on flower diameter in carnation (Dianthus caryophyllus)

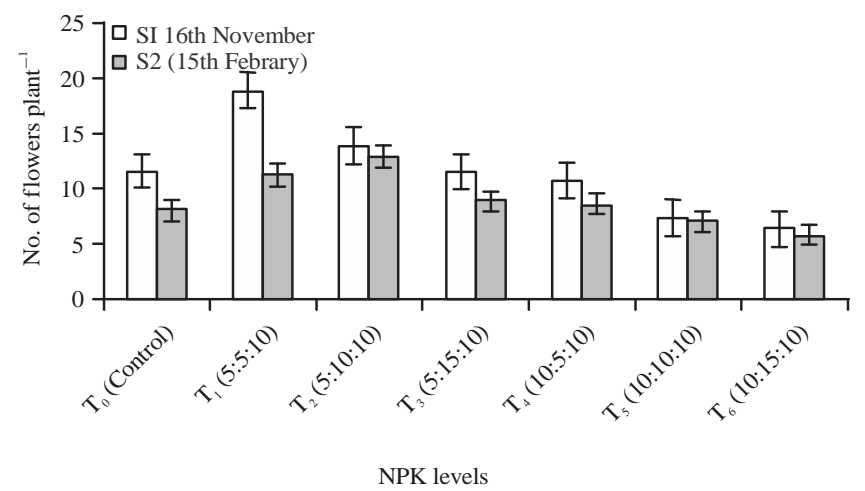

Fig. 13: Effect of planting seasons and macro nutritional (NPK) levels on number of flowers per plant in carnation (Dianthus caryophyllus)

$\mathrm{T}_{5}\left(10: 10: 10\right.$ g pot $\left.^{-1} \mathrm{NPK}\right)$ and $\mathrm{T}_{6}\left(10: 15: 10 \mathrm{~g} \mathrm{pot}^{-1} \mathrm{NPK}\right)$ was at bottom with 7.33 and 6.30 flowers $^{-1 a n t^{-1}}$, respectively (Fig. 13). As in planting season $\mathrm{S}_{2}$ (15th Feb.) is concerned, $\mathrm{T}_{2}$ (5:10:10 $\left.\mathrm{g} \mathrm{pot}^{-1} \mathrm{NPK}\right)$ produced maximum with 12.90 flowers plant ${ }^{-1}$ followed by $T_{1}\left(5: 5: 10\right.$ g pot $\left.^{-1} \mathrm{NPK}\right)$ with 11.33 flowers plant ${ }^{-1}$. While, $\mathrm{T}_{5} \quad\left(10: 10: 10 \mathrm{~g} \operatorname{pot}^{-1}\right.$ NPK $)$ and $T_{6}$ (10:15:10 g pot ${ }^{-1}$ NPK) was at bottom with 7.10 and 5.80 flowers plant $^{-1}$, respectively.
Treatment $\mathrm{T}_{3}$ (5:15:10 g pot $\left.{ }^{-1} \mathrm{NPK}\right)$ produced maximum (2.02 g) fresh weight of flower and $\mathrm{T}_{0}$ (Control) produced minimum (1.10 g) fresh weight of a flower in $S_{1}$ (16th Nov.) planting season. Treatment $T_{3}$ (5:15:10 $\left.\mathrm{g} \mathrm{pot}^{-1} \mathrm{NPK}\right)$ also produced maximum (1.67 g) fresh weight and $\mathrm{T}_{0}$ (Control) minimum (1.14 g) (Fig. 14).

According to the data presented in Fig. 15, $\mathrm{T}_{3}$ (5:15:10 g pot ${ }^{-1} \mathrm{NPK}$ ) produced maximum dry weight of 
Sci. Technol. Dev., 34 (3): 169-178, 2015

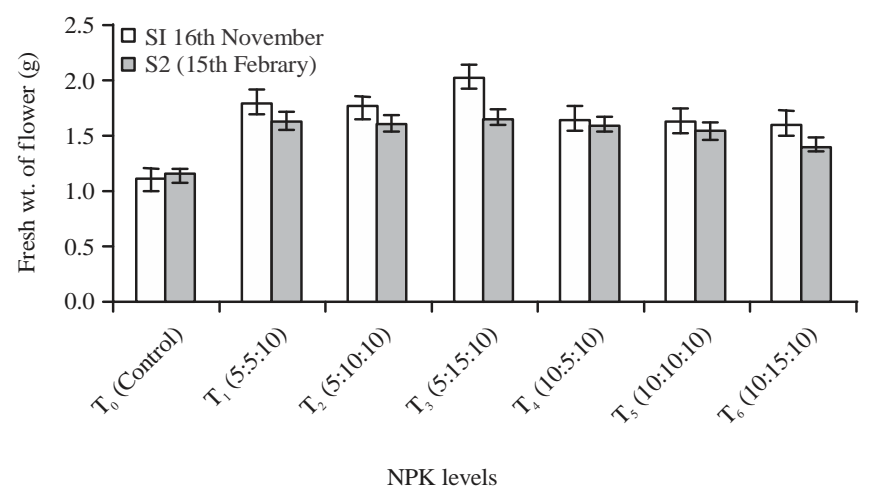

Fig. 14: Effect of planting seasons and macro nutritional (NPK) levels on fresh weight of flowers in carnation (Dianthus caryophyllus)

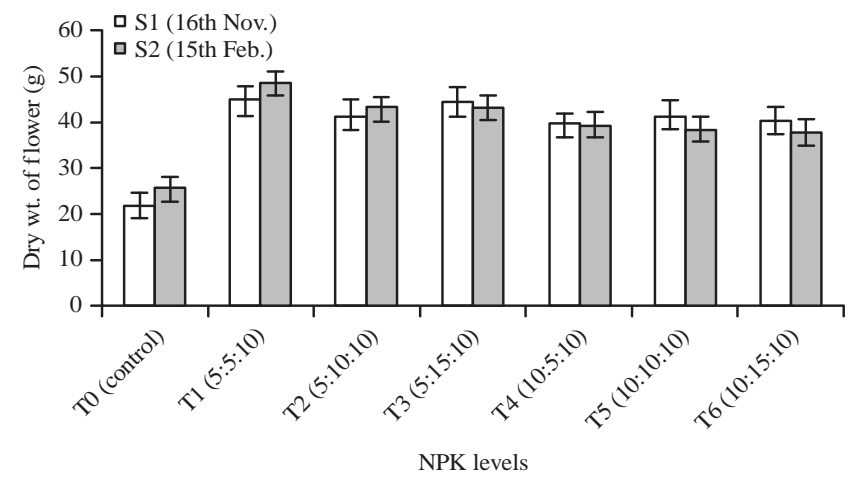

Fig. 15: Effect of planting seasons and macro nutritional (NPK) levels on dry weight of flowers in carnation (Dianthus caryophyllus)

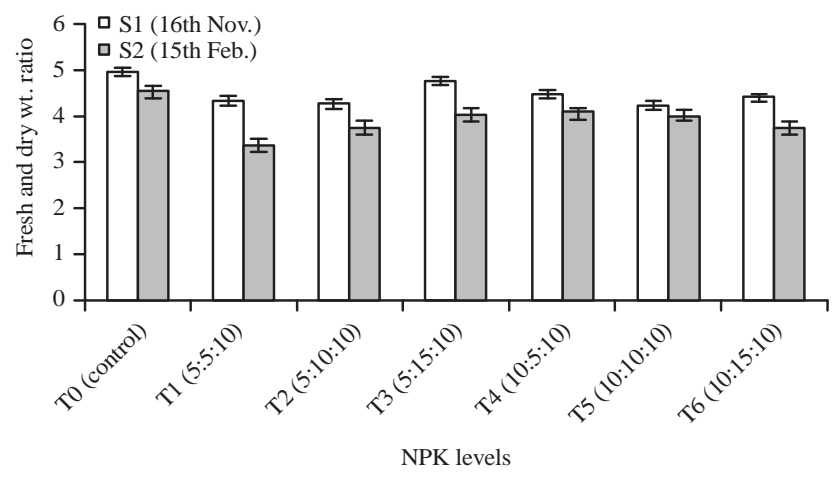

Fig. 16: Effect of planting seasons and macro nutritional (NPK) levels on fresh and dry weight ratio in carnation (Dianthus caryophyllus)

a flower $(0.45 \mathrm{~g})$ in $\mathrm{S}_{1}$ (16th Nov.) planting season but While $\mathrm{T}_{0}$ (Control) was at bottom by producing $0.22 \mathrm{~g}$ dry weight of a flower. In planting season $\mathrm{S}_{2}$ (15th Feb.) treatment $\mathrm{T}_{1}\left(5: 5: 10 \mathrm{~g} \mathrm{pot}^{-1} \mathrm{NPK}\right)$ produced maximum $(0.45 \mathrm{~g})$ dry weight of a flower, while $\mathrm{T}_{0}$ (Control) produced $(0.26 \mathrm{~g})$ dry weight of flower.

Maximum (4.98) fresh and dry weight ratio in $\mathrm{S}_{1}$ (16th Nov.) planting season was in $\mathrm{T}_{0}$ (Control) followed by $T_{3}\left(5: 15: 10 \mathrm{~g} \mathrm{pot}^{-1}\right.$ NPK) with 4.77. While $T_{5}\left(10: 10: 10 \mathrm{~g} \mathrm{pot}^{-1} \mathrm{NPK}\right)$, was at bottom with 4.26 fresh and dry weight ratio (Fig. 16). Maximum (4.55) fresh and dry weight ratio in $S_{2}$ (15th Feb.) planting season was produced in $\mathrm{T}_{0}$ (Control) followed by $\mathrm{T}_{4}\left(10: 5: 10 \mathrm{~g} \mathrm{pot}^{-1} \mathrm{NPK}\right)$ with 4.08 . But T1 (5:5:10 g pot ${ }^{-1}$ NPK) was at bottom with 3.38 fresh and dry weight ratio. 
Sci. Technol. Dev., 34 (3): 169-178, 2015

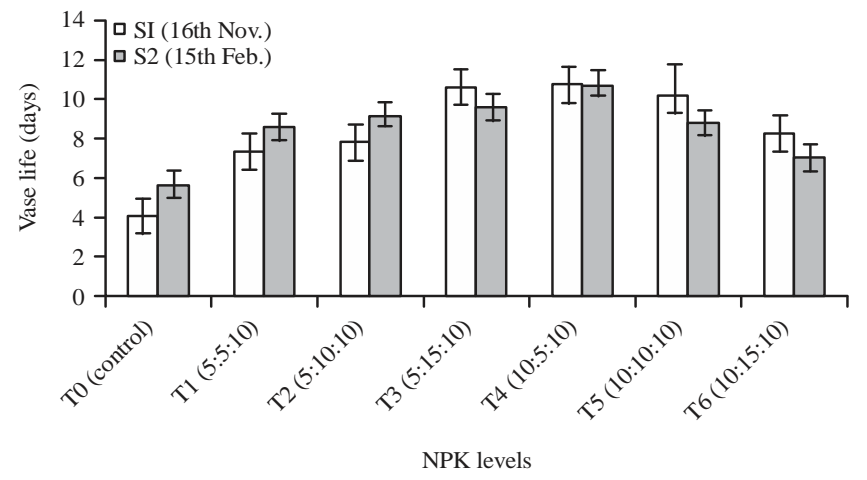

Fig. 17: Effect of planting seasons and macro nutritional (NPK) levels on vase life of carnation (Dianthus caryophyllus)

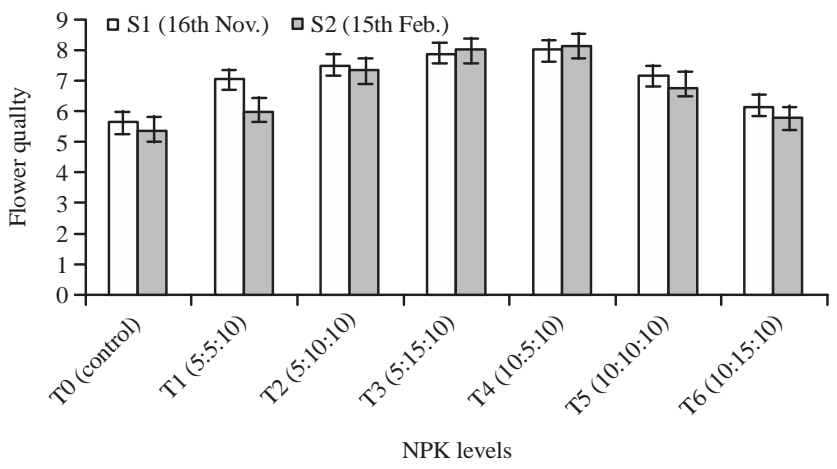

Fig. 18: Effect of planting seasons and macro nutritional (NPK) levels on flower quality of carnation (Dianthus caryophyllus)

In planting season $S_{1}$ (16th Nov.), $T_{4}$ (10:5:10 g pot $^{-1}$ NPK) gave maximum flower vase life with 10.83 days followed by $\mathrm{T}_{3}$ (5:15:10 $\left.\mathrm{g} \mathrm{pot}^{-1} \mathrm{NPK}\right)$ with 10.70 days (Fig. 17). But treatment without growth regulator gave minimum 4.06 days vase life. In case of $S_{2}$ (15th Feb.) planting season, $\mathrm{T}_{4}\left(10: 5: 10 \mathrm{~g} \mathrm{pot}^{-1} \mathrm{NPK}\right)$ gave maximum flower vase life with 10.87 days followed by $\mathrm{T}_{3}$ (5:15:10 g pot $^{-1} \mathrm{NPK}$ ) with 9.67 days. While $\mathrm{T}_{0}$ (Control) was at bottom with 5.67 days vase life.

Data in Fig. 18 showed that $\mathrm{T}_{4}$ (10:5:10 $\left.\mathrm{g} \mathrm{pot}^{-1} \mathrm{NPK}\right)$ produced highest flower quality score with 7.97 followed by $\mathrm{T}_{3}\left(5: 15: 10 \mathrm{~g} \mathrm{pot}^{-1} \mathrm{NPK}\right)$ with 7.83 in $\mathrm{S}_{1}$ (16th Nov.) planting season but minimum flower quality was observed $\mathrm{T}_{0}$ (Control) with 5.61 quality point. In planting season $S_{2}$ (15th Feb.), $T_{4}$ (10:5:10 g pot ${ }^{-1}$ NPK) gave maximum flower quality score with 8.10 followed by $\mathrm{T}_{3}$ (5:15:10 $\mathrm{g} \mathrm{pot}^{-1} \mathrm{NPK}$ ) with 7.97. While $\mathrm{T}_{0}$ (Control) gave minimum results with 5.37 quality point (Fig. 18).

\section{CONCLUSION}

It was concluded that the overall best performance of carnation production such as plant height, number of branches per plant, length of branches, number of leaves per plant, leaf area, NPK contents, flower diameter, flower quality and vase life was due to $T_{2}$ (5:10:10 $\mathrm{g} \mathrm{pot}^{-1} \mathrm{NPK}$ ) as for as macro nutritional (NPK) effect was concerned. Whereas, planting season $\mathrm{S}_{1}$ (16th Nov.) performed better as compared to planting season $\mathrm{S}_{2}$ (15th Feb.).

\section{REFERENCES}

Bloome, R. and G. Roels, 1977. Fertilizing American carnation with nitrogen. Verbondsniccure Voor Belgische Sirteatt, 21: 713-714.

Damke, M.M. and S.K. Bhattacharjee, 1997. Influence of NPK fertilisation on flower yield and seasonal changes in leaf nutrient content of rose cv. super star. Res. J. Punjabrao Krishi Vidyapeeth, 21: 39-43.

Default, R.J., 1987. Use of slow-release nitrogen and phosphorus fertilizers in celery transplant production. HortScience, 22: 1268-1270.

Gursan, K., 1999. Effect of different planting times on carnation flower yield and distribution of year-round yield in yalova. Acta Horticult., 491: 415-420. 
Indrajit, S. and R. Nilimesh, 2003. Effect of nitrogen and phosphorus on the growth and flowering of carnation cv. Chabaud mixed under open condition. Environ. Ecol., 21: 696-698.

Khan, M.S., K. Ziaf and I. Ahmad, 2004. Influence of nitrogen on growth and flowering of Zinnia elegans Cv. meteor. Asian J. Plant Sci., 3: 571-573.

Kumar, R. and K. Kaur, 1996. Effect of nitrogen and phosphorous on plant growth, pod number and seed yield in balsam (Impatiens balsamina L.). J. Orn. Hortic., 4: 23-26.

Nukui, H., S. Kudo, A. Yamashita and S. Satoh, 2004. Repressed ethylene production in the gynoecium of long-lasting flowers of the carnation 'White Candle': Role of the gynoecium in carnation flower senescence. J. Exp. Bot., 55: 641-650.

Shah, A., S.D. Lal and J.N. Seth, 1984. Effect of different levels of nitrogen and phosphorus on growth, flowering and corm yield of gladiolus ex. Vinks Glory. Prog. Hort., 16: 305-307.
Sharaf, A.I. and A.H. Ei-Naggar, 2003. Effect of carnation plant to phosphorus and boron foliage fertilization under green house conditions. Alexandria J. Agric. Res., 48: 147-158.

Steel, R.G.D., J.H. Torrie and D.A. Dickey, 1997. Principles and Procedures of Statistics: A Biometrical Approach. 3rd Edn., McGraw-Hill Co., New York, USA., ISBN: 9780070610286, Pages: 666.

Van Iersel, M.W., R.B. Beverly, P.A. Thomas, J.G. Latimer and H.A. Mills, 1998. Fertilizer effects on the growth of impatiens, petunia, salvia and vinca plug seedlings. HortScience, 33: 678-682.

Van Lierop, W.M., 1976. Digestion procedures for simultaneous automated determination of $\mathrm{NH}+, \mathrm{P}, \mathrm{K}$, Ca and Mg in plant material. Can. J. Soil Sci., 56: 425-432.

Zizzo, G.V., G. Fascella and S. Agnello, 1999. Tuberose, effect of flowering of planting date and bulb size. Istituto Sperimentale per la Floricoltura, Sezioneoperativaperiferica di Palermo, Italy. 